ISSN 1392-3196 / e-ISSN 2335-8947

Zemdirbyste-Agriculture, vol. 107, No. 2 (2020), p. 185-190

DOI 10.13080/z-a.2020.107.024

\title{
The variation of the content of dehydrin proteins in the bark of Malus app. trees differing in winter hardiness in Southern Cisbaikalia conditions
}

\author{
Maxim A. RACHENKO, Anna M. RACHENKO \\ Siberian Institute of Plant Physiology and Biochemistry \\ of the Siberian Branch of the Russian Academy of Sciences \\ Lermontova 132, 664033 Irkutsk, Russia \\ E-mail: bigmks73@rambler.ru
}

\begin{abstract}
The aim of the research was to study the dynamics of dehydrine proteins of apple (Malus spp.) trees in Southern Cisbaikalia conditions. Siberian berry apple tree and domestic or cultivated apple tree as well as their interspecific hybrids of various crossing generations, that showed differences in winter hardiness in field studies, were used as the object of the research. Samples of plant material were collected monthly (September to May) during two experimental years. The results showed that the qualitative composition of dehydrins in the bark of an apple tree did not depend on the cultivar. Proteins with a mass of $63,60,52,45,34$ and $32 \mathrm{kD}$ were determined in the dehydrin spectrum of all the studied apple tree genotypes. Dehydrin with a molecular mass of $52 \mathrm{kDa}$ was present throughout the dormancy. The number of other proteins varied depending on the season. Significant differences were found for proteins with masses of 60 and $34 \mathrm{kDa}$. The revealed peculiarities of the $34 \mathrm{kDa}$ protein content can be associated with the adaptive potential of apple trees in the conditions of Southern Cisbaikalia.
\end{abstract}

Key words: apple tree, cultivars, dehydrins, winter hardiness.

\section{Introduction}

Cold and frost hardiness is a dynamic resultant property of many factors and changes over time. The development of cold hardiness in woody plants can be divided into five components: induction time of cold acclimatization, rate of acclimatization, degree of frost hardiness to be achieved, preservation of frost hardiness during the winter months and rate of frost hardiness loss when spring growth resumes (Gusta, Wisniewski, 2013). Presumably, each hardiness component is due to its own set of biochemical factors. The study of these factors will make it possible to assess the winter hardiness of the existing and newly created cultivars at the biochemical level. Dehydrin proteins, the cryoprotective function of which has been shown in many studies, are one of those factors (Kosová et al., 2010; Tatarinova et al., 2011; Ponomarev et al., 2013; Strimbeck et al., 2015; Salojärvi et al., 2017)

Elucidation of hardiness mechanisms of woody plants to low temperatures is possible with the help of some experimental models. In a warm climate, where no large amplitude of temperatures in the plus and minus sides is observed, the use of plant genotypes that are sensitive or resistant to a small temperature drop can be helpful (Arora, Rowland, 2011; Shin et al., 2015; Palmer, 2017; Zamani Bahramabadi et al., 2018). In regions with a temperate and continental climate, the study of either one plant species in different climatic conditions (Tatarinova et al., 2017) or the use of different ecotypes of the same species or different species of the same genus in research (Fernández et al., 2012; Vasilyeva et al., 2018) can be of interest.

An example is the genus Malus, the species composition of which is very diverse both in terms of habitat and frost hardiness (Ponomarenko, Ponomarenko, 2012). The most frost-hardy cultivar of apple is Malus baccata Borkh., or Siberian berry apple, the aboveground part of which is able to withstand temperatures up to $-55^{\circ} \mathrm{C}$. The development of gardening in Siberia has become possible only thanks to this apple cultivar. After $M$. baccata and $M$. domestica were crossbred, Siberian crab-apple trees with winter hardiness closest to that of Siberian apple trees were obtained as well as semicultivated apple trees, whose winter hardiness varies depending on the distance from the parent species and is most often associated with the size of the fruit (Rachenko et al., 2011).

The current study was aimed to find out the way the qualitative and quantitative composition of dehydrin proteins changes in the bark of the selected apple tree genotypes differing in winter hardiness in the conditions

Please use the following format when citing the article:

Rachenko M. A., Rachenko A. M. 2020. The variation of the content of dehydrin proteins in the bark of Malus app. trees differing in winter hardiness in Southern Cisbaikalia conditions. Zemdirbyste-Agriculture, 107 (2): 185-190. DOI 10.13080/z-a.2020.107.024 
of Southern Cisbaikalia. Field studies and laboratory experiments on artificial freezing allowed us to show the differences in winter hardiness of the selected apple genotypes.

\section{Materials and methods}

Plant material. The studies were carried out in the collection garden of Siberian Institute of Plant Physiology and Biochemistry, Siberian Branch of the Russian Academy of Sciences. Apple trees were of the same age, grown in equal agronomic conditions. The number of trees of each cultivar differed from 2 to 4 . Siberian berry apple (Malus baccata Borkh.) tree was used as a stock tree. Table shows the cultivars used in the experiments and their origin.

Table. Origin of the cultivars used in the experiments
The current year branches located above the snow cover served as the study material. The plant material samples were collected monthly from September to May during two (2010-2012) experimental years. The bark from the branches was removed and frozen in liquid nitrogen. The samples were stored in the ultra-low temperature freezer (Sanyo Electric Co. Ltd., Japan) at $-80^{\circ} \mathrm{C}$ until the protein isolation.

Protein extraction, SDS-PAGE and immunoblotting. The method of Arora et al. (1992) with minor modifications was used for protein extraction. Next, total protein of $3 \mathrm{~g}$ of plant material was extracted. For heat-stable protein fractions the samples were treated at $100^{\circ} \mathrm{C}$ in a water bath for 10 min followed by centrifugation at $15.000 \mathrm{rpm}$ for $20 \mathrm{~min}$. The protein concentration was determined according to the Lowry

\begin{tabular}{ll}
\hline \multicolumn{1}{c}{ Cultivar } & \multicolumn{1}{c}{ Origin } \\
\hline Malus domestica 'Papirovka' & $\begin{array}{l}\text { People's selection } \\
\text { People's selection } \\
\text { Malus baccata } \times \text { M. domestica 'Purpurovaya' } \\
\text { Central Siberian Botanical Garden, } \\
\text { Siberian Branch of the Russian Academy of Sciences }\end{array}$ \\
$\begin{array}{l}\text { Malus baccata } \times \text { M. domestica } \times M \text {. domestica } \\
\text { 'Krasa Buryatii' }\end{array}$ & Buryat Fruit and Berry Experimental Station \\
$\begin{array}{l}\text { Malus baccata } \times \text { M. domestica } \times M . \text { domestica } \\
\text { 'Altayskoye Rumyanoye' }\end{array}$ & Research Institute of Horticulture of Siberia named after M. A. Lisavenko \\
Malus baccata $($ control) & Siberian berry apple tree seedling from the native habitat
\end{tabular}

(Lowry et al., 1951) method. The supernatants were loaded on two parallel 14\% SDS-PAGE (sodium dodecyl sulphate-polyacrylamide gel electrophoresis) gels along with molecular weight markers (Sigma, USA). The separations were performed with a Mini-PROTEAN 3 (Bio-Rad, USA) equipment according to Laemmli (1970). The protein concentration per track was $30 \mu \mathrm{g}$. One of the gels was stained with Coomassie Brilliant Blue (Sigma, USA) for visualization of protein content. The other gel was blotted onto a nitrocellulose membrane (Whatman, Protran BA85, Sigma-Aldrich) according to the manufacturer's instructions. The membrane was probed with anti-dehydrin affinity-purified IgG antibody (Agrisera AS07 206, Sweden), which had been raised against the K-segment consensus sequence epitope (Timmons, Dunbar, 1990). Thereafter, the membrane was incubated with alkaline phosphatase conjugated secondary AffiniPure Goat Anti-Rabbit IgG antibody (Jackson ImmunoResearch Laboratories Inc., USA).

\section{Results}

Climatic conditions of the research area and winter hardiness of apple trees. It has been proven that the winter hardiness of fruit plants is in most cases conditioned by their frost hardiness - a biological property of plants, which allows them to withstand low negative temperatures and determines their natural habitat, durability and productivity. Undoubtedly, Siberia can be considered the most severe climatic region, where horticulture is developed in a varying degree. Southern Cisbaikalia is part of Siberia with observed annual climate fluctuations. That is expressed in the winter period features, such as the sum of negative temperatures, the presence of periods with extremely low temperatures and their duration and the amount of snow cover. The growing season conditions (its duration, the sum of positive temperatures and the amount of precipitation) should be indisputably considered very important. The duration of autumn hardening and a gradual decrease in temperature from positive in September to low negative in October-November have an equally significant effect on the successful wintering of fruit trees. Significant temperature differences and high insolation increase the damage risk in early spring. Over the twenty-year period of our observations, the number of years with favourable climatic conditions (necessary period of autumn hardening, warm winter without periods of extremely low temperatures, early and rapid spring warming without strong temperature fluctuations) was small: 2006-2007, 2007-2008, 2013-2014 and 20142015. During the rest of the years, particular deviations related to the onset and going through all the phases of plant dormancy were observed. Namely the resistance to these deviations determines the possibility of longterm cultivation of plants (apple trees in our case) in the conditions of the research region. Experiments to study the content of dehydrins in the bark of apple trees were carried out in the years (2010-2012) with contrasting weather conditions.

Many researchers have proved the impossibility of growing Malus domestica in an open form in Siberia. Even the most winter-hardy cultivars of this apple cultivar freeze up to the level of snow cover within 3-5 years. This was the reason for creating the scrubby form of a fruit tree, which makes it possible to completely cover it with snow. In this case, a large number of $M$. domestica survive the Siberian winter and produce crops.

The hybridization of Siberian berry apple with M. domestica cultivars gave rise to several groups of 
Siberian cultivars: crab-apples with fruit weights from $8 \mathrm{~g}$ to $25 \mathrm{~g}$, small-fruited semi-cultures - from $30 \mathrm{~g}$ to $50 \mathrm{~g}$, large-fruited semi-cultures - from 60 to $100 \mathrm{~g}$. A longterm study of Southern Cisbaikalia apple tree cultivars belonging to different groups allowed us to characterize their winter hardiness. Crab-apples 'Purpurovaya' and 'Veselovka', small-fruited semi-culture 'Krasa Buryatii', large-fruited semi-culture 'Altayskoye Rumyanoye', cultivated apple-tree 'Papirovka' and Siberian berry apple tree were chosen for the experiments.

The qualitative and quantitative composition of dehydrins in an apple tree bark. From the amount of protein synthesized, dehydrins are the main mechanism for adaptation to low temperature in M. domestica (Haimi et al., 2017). It is most likely true for other species of the genus Malus, too.
Results of our experiment showed that differences in the accumulation of dehydrins were observed as early as in September-October (Fig. 1). In September, we determined dehydrins in the bark of Siberian apple tree $(60 \mathrm{kDa})$, 'Purpurovaya' $(63,60$ and $52 \mathrm{kDa}$ ), 'Altayskoye Rumyanoye' (60, 52 and $34 \mathrm{kDa})$ and 'Papirovka' (63, 60, 52, 34 and $32 \mathrm{kDa})$. In October, the spectrum of detectable dehydrins expanded in Siberian apple trees (proteins with a mass of 52 and $34 \mathrm{kDa}$ appeared): 'Purpurovaya' (34 kDa), 'Veselovka' and 'Krasa Buryatii' (63, 52 and $34 \mathrm{kDa})$, 'Altayskoye Rumyanoye' (63 and $32 \mathrm{kDa}$ ). The most pronounced dynamics of dehydrin is with a mass of $34 \mathrm{kDa}$. In September, this was a major protein only in the bark of the winter-non-hardy 'Papirovka'. It was also determined in a small amount in the bark of the 'Altayskoye Rumyanoye'.

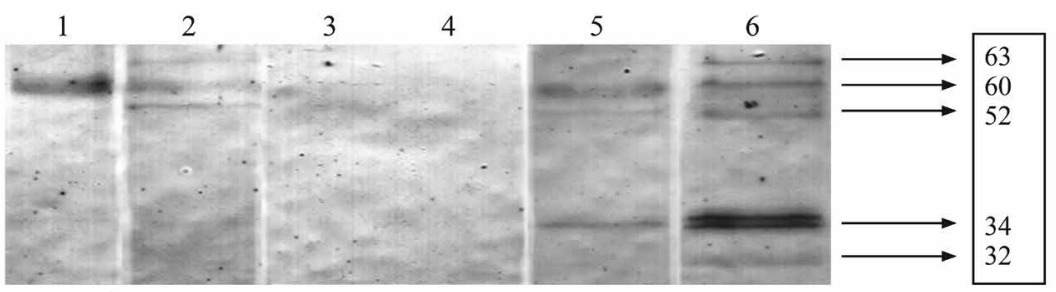

September

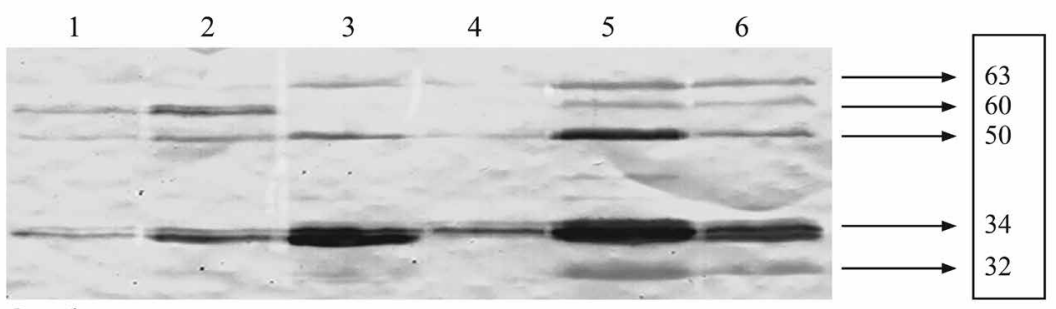

October

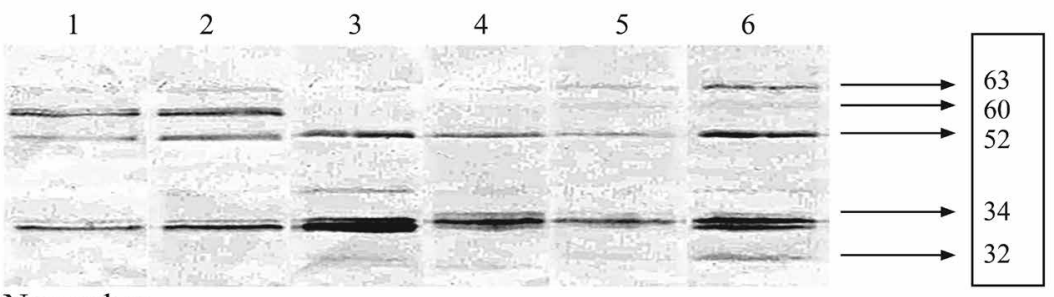

November

1 - Siberian berry apple, 2 - 'Purpurovaya', 3 - 'Veselovka', 4 - 'Krasa Buryatii', 5 - 'Altayskoye Rumyanoye', 6 - 'Papirovka'

Figure 1. Changes in the spectrum of dehydrins of apple tree bark in the autumn

In October, it appeared in the samples of all the studied cultivars and was particularly pronounced in 'Altayskoye Rumyanoye' and 'Veselovka'. In November, the amount of protein was visually levelled off in the samples of all the studied cultivars.

In December and January, the quantity of dehydrins in the bark of Siberian apple and 'Purpurovaya' reached a maximum, while in 'Altayskoye Rumyanoye' and 'Papirovka' it reduced to a minimum, and only proteins with a molecular mass of 60 and $52 \mathrm{kDa}$ were determined (Fig. 2). Dehydrin with a mass of $34 \mathrm{kDa}$ was determined only in winter-hardy cultivars 'Purpurovaya', 'Veselovka', 'Krasa Buryatii' and Siberian berry apple. It was not determined in the bark of the 'Papirovka'. In February, only 63, 52 and $34 \mathrm{kDa}$ proteins were determined in Siberian crab-apple and 'Purpurovaya'. The spectrum of determined dehydrins in the bark of
'Altayskoye Rumyanoye' and 'Papirovka' significantly expanded $(63,60,52,64$ and $32 \mathrm{kDa})$, and the $32 \mathrm{kDa}$ protein grew major.

In March, the $34 \mathrm{kDa}$ protein, which was no longer determined in the bark of any winter-hardy cultivar, lined up with the $32 \mathrm{kDa}$ protein (Fig. 3). In April, by the time of forced dormancy end, the 32 and $34 \mathrm{kDa}$ proteins were no longer determined in any of the cultivars, but the $45 \mathrm{kDa}$ protein appeared. The appearance of this protein can most likely be associated with the loss of hardening. In May, only dehydrins with a molecular mass of 63 and $52 \mathrm{kDa}$ were determined and only in the bark of Siberian apple trees 'Purpurovaya', 'Veselovka' and 'Krasa Buryatii'. 


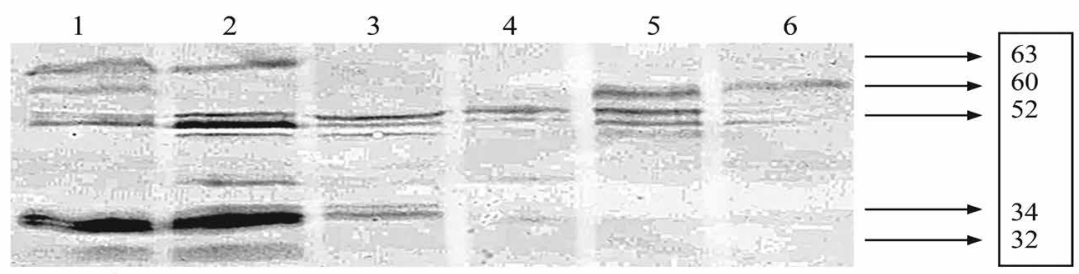

December

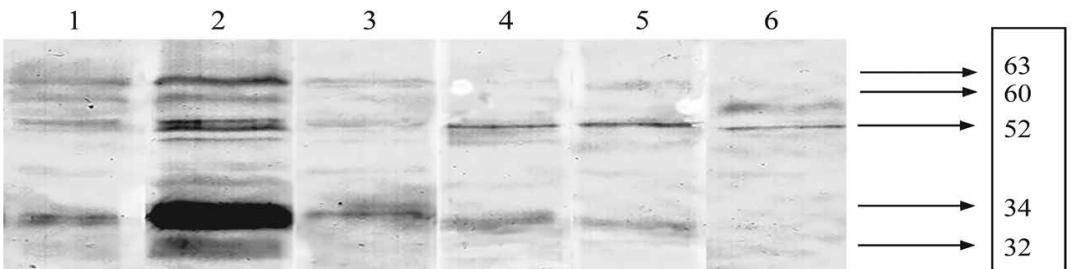

January

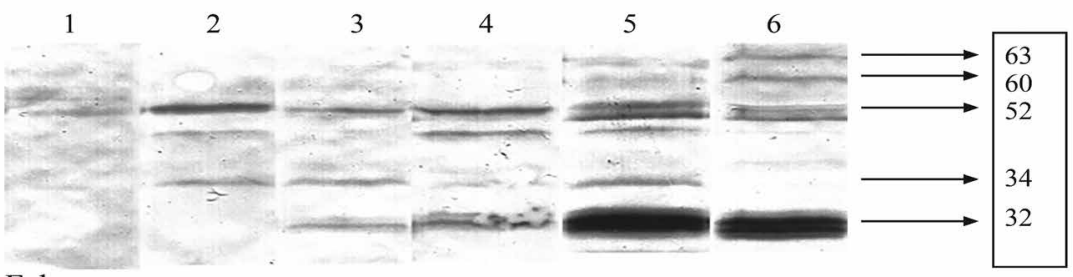

February

1 - Siberian berry apple, 2 - 'Purpurovaya', 3 - 'Veselovka', 4 - 'Krasa Buryatii', 5 - 'Altayskoye Rumyanoye', 6 - 'Papirovka'

Figure 2. Changes in the spectrum of dehydrins of apple tree bark in the winter

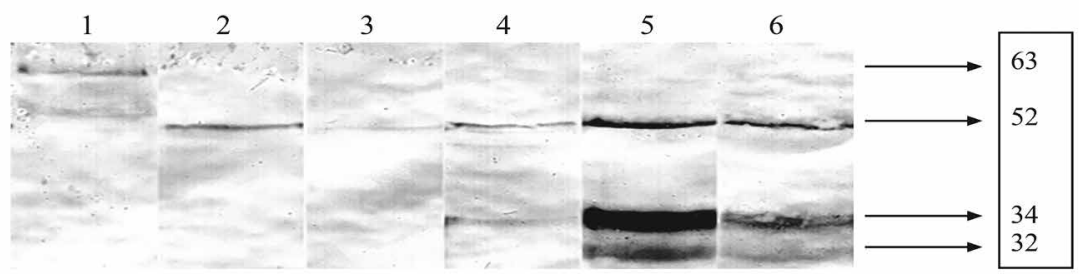

March

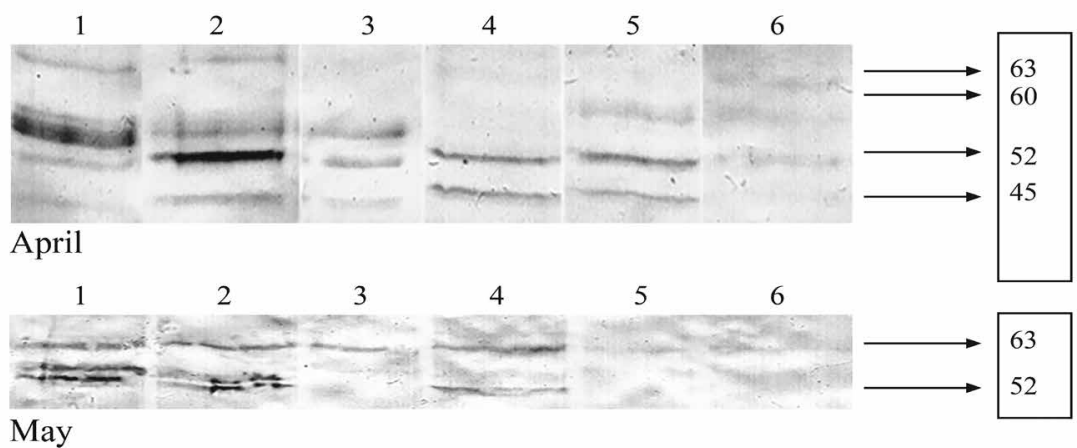

1 - Siberian berry apple, 2 - 'Purpurovaya', 3 - 'Veselovka', 4 - 'Krasa Buryatii', 5 - 'Altayskoye Rumyanoye', 6 - 'Papirovka'

Figure 3. Changes in the spectrum of dehydrins of apple tree bark in the spring

\section{Discussion}

Woody plants can adapt to harsh winters due to a process called cold acclimatization. Thanks to this process, they develop resistance to low temperatures and seasonal freezing. The frost resistance increases in the autumn, peaks in mid-winter, decreases in the spring and reaches its lowest level in the summer (Arora, Taulavuori, 2016). Cold acclimatization is considered an active process, which consists of a wide range of physiological and biochemical reprogramming. It includes the altered structure and function of a membrane as well as many changes in the primary and secondary metabolism, most of which are also accompanied by related changes in the protein / gene expression (Janská et al., 2010; Preston, Sandve, 2013). Dehydrins play an important role in protecting plants from dehydration stresses, including stress imposed by freeze-drying (Wisniewski et al., 2003; Tunnacliffe, Wise, 2007). Their accumulation is one of the fundamental responses of plants to cold stress (Maleki, Ghorbanpour, 2018).

There are only few works related to the study of seasonal dynamics of dehydrins in woody plants in general and in fruit plants in particular. These works mainly consist of studies conducted on trees grown 
in a warm climate. It was shown that during cold acclimatization, dehydrins with a molecular mass of 65,60 and $14 \mathrm{kDa}$ accumulate in the blueberry flower buds (Polashock et al., 2010). Immunological studies showed that a polypeptide with a molecular mass of $60 \mathrm{kDa}$ isolated from peach xylem tissue is a dehydrin (Yamane, 2014).

When comparing the pool of dehydrins in dormant flower buds of Japanese apricot cultivars differing in cold hardiness, it was found that in a frosthardy cultivar, the quantity of dehydrin protein and its transcripts was higher than that in an evergreen cultivar (Sasaki et al., 2011). In M. domestica apple tree bark, a major dehydrin with a molecular mass of $47 \mathrm{kDa}$ was found (Wisniewski et al., 2014). In response to a decrease in temperature, the level of transcripts of the four dehydrin proteins identified in the Asian pear (Prunus pyrifolia) increased significantly (Hussain et al., 2015). Changes in the expression of dehydrins genes among different cultivars of apple trees during the winter have been shown. Thus, their key role in passing through dormancy of this fruit tree is recognized (da Silveira Falavigna et al., 2014; 2015).

Dehydrins are considered mainly as hardening proteins, and there are very few data on seasonal changes in the spectrum of these proteins under conditions of low negative temperature. The study of gene expression in response to a decrease in temperature in buds of three different birch ecotypes growing in the central part of Finland showed that the transcripts of one of the genes coding dehydrin BpuDhn2 reached their highest level by February; the maximum of transcripts of the second gene of dehydrin BpuDhnl was observed in October, and by February their number was significantly reduced. The different function of the products of these genes was suggested at different stages of plant hardiness development (Gusta, Wisniewski, 2013).

Yakut scientists suggested in their works that the group of low-molecular dehydrins with a molecular mass of 15-21 kDa was associated with the cold hardiness of Betula platyphylla (Ponomarev et al., 2013).

\section{Conclusion}

The results of the study showed that the qualitative composition of dehydrins in an apple (Malus spp.) tree bark did not depend on the cultivar. The same spectrum $(63,60,52,45,34$ and $32 \mathrm{kDa})$ of dehydrins was determined in all the genotypes studied at different time intervals. The number of these proteins varied depending on the season. This is likely to be connected with the difference in the cold acclimatization degree of each cultivar. Dehydrin with a molecular mass of $52 \mathrm{kDa}$ was observed throughout the dormancy.

The number of other proteins was constantly changing. Significant differences were found for proteins with masses of 60 and $34 \mathrm{kDa}$. At different times, the $60 \mathrm{kDa}$ protein was determined in the highly winter-hardy genotypes of Malus baccata (Siberian berry apple): the crab-apple 'Purpurovaya', the low-winter-hardy semiculture 'Altayskoye Rumyanoye' and the cultivated apple-tree 'Papirovka'; it was absent in the semi-cultures 'Krasa Buryatii' and 'Veselovka'. In the autumn months, the $34 \mathrm{kDa}$ dehydrin was observed in the protein spectrum of all the genotypes studied. By the middle of winter (December-January), this protein was mainly determined in highly winter-hardy cultivars. It is likely that this determines their stable state during this time. In February, the $34 \mathrm{kDa}$ dehydrin disappeared from the spectra of M. baccata and the crab-apple 'Purpurovaya'. By March, it was determined only in the semi-culture 'Altayskoye Rumyanoye' and the cultivated apple-tree 'Papirovka'.

Based on the data obtained, the $34 \mathrm{kDa}$ protein is highly unlikely to play a decisive role in the winter hardiness of apple trees. However, the peculiarities of the $34 \mathrm{kDa}$ protein content we identified in the studied apple trees can be undoubtedly associated with the adaptive potential necessary for wintering in the conditions of Southern Cisbaikalia.

\section{Acknowledgements}

The research was done using the equipment of The Core Facilities Center "Bioanalytics" and the collection of The Core Facilities Center "Bioresource Center" of Siberian Institute of Plant Physiology and Biochemistry Siberian Branch of the Russian Academy of Sciences.

Received 21062019

Accepted 21112019

\section{References}

1. Arora R., Rowland L. J. 2011. Physiological research on winter-hardiness: deacclimation resistance, reacclimation ability, photoprotection strategies, and a cold acclimation protocol design. HortScience, 46 (8): 1070-1078. https://doi.org/10.21273/HORTSCI.46.8.1070

2. Arora R., Taulavuori K. 2016. Increased risk of freeze damage in woody perennials VIS-À-VIS climate change: Importance of deacclimation and dormancy response. Frontiers in Environmental Science, 4: 44. https://doi.org/10.3389/fenvs.2016.00044

3. Arora R., Wisniewski M. E., Scorza R. 1992. Cold acclimation in genetically related (sibling) deciduous and evergreen peach (Prunus persica L. Batsch). I. Seasonal changes in cold hardiness and polypeptides of bark and xylem tissues. Plant Physiology, 99 (4): 1562-1568. https://doi.org/10.1104/pp.99.4.1562

4. da Silveira Falavigna V., Porto D. D., Buffon V., MargisPinheiro M., Pasquali G., Revers L. F. 2014. Differential transcriptional profiles of dormancy-related genes in apple buds. Plant Molecular Biology Reporter, 32 (4): 796-813. https://doi.org/10.1007/s11105-013-0690-0

5. da Silveira Falavigna V., Miotto Y. E., Porto D. D. Anzanello R., Santos H. P. D., Fialho F. B., Revers L. F. 2015. Functional diversification of the dehydrin gene family in apple and its contribution to cold acclimation during dormancy. Physiologia Plantarum, 155 (3): 315329. https://doi.org/10.1111/ppl.12338

6. Fernández M., Valenzuela S., Barraza H., Latorre J., Neira V. 2012. Photoperiod, temperature and water deficit differentially regulate the expression of four dehydrin genes from Eucalyptus globulus. Trees, 26 (5): 1483-1493. https://doi.org/10.1007/s00468-012-0722-7

7. Gusta L. V., Wisniewski M. 2013. Understanding plant cold hardiness: an opinion. Physiologia Plantarum, 147 (1): 4-14. https://doi.org/10.1111/j.1399-3054.2012.01611.x

8. Haimi P., Vinskienė J., Stepulaitienè I., Baniulis D., Stanienè G., Šikšnianienè J. B., Rugienius R. 2017. Patterns of low temperature induced accumulation of dehydrins in Rosaceae crops - evidence for post-translational modification in apple. Journal of Plant Physiology, 218: 175-181. https://doi.org/10.1016/j.jplph.2017.08.008

9. Hussain S., Niu Q., Qian M., Bai S., Teng Y. 2015. Genomewide identification, characterization, and expression analysis of the dehydrin gene family in Asian pear (Pyrus pyrifolia). Tree Genetics and Genomes, 11 (5): 110 https://doi.org/10.1007/s11295-015-0938-y

10. Janská A., Maršík P., Zelenková S., Ovesná J. 2010. Cold stress and acclimation - what is important for metabolic adjustmen? Plant Biology, 12 (3): 395-405 https://doi.org/10.1111/j.1438-8677.2009.00299.x

11. Kosová K., Prášil I. T., Vítámvás P. 2010. Role of dehydrins in plant stress response. Handbook of plant and crop stress ( $3^{\text {rd }}$ ed.), chapter 10 , p. 239-257. https://doi.org/10.1201/b10329-13 
12. Laemmli U. 1970. Relevant page on gel electrophoresis. Nature, 227: 681. https://doi.org/10.1038/227680a0

13. Lowry O. H., Rosebrough N. J., Farr A. L., Randall R. J. 1951. Protein measurement with the Folin phenol reagent. Journal of Biological Chemistry, 193: 265-275.

14. Maleki M., Ghorbanpour M. 2018. Cold tolerance in plants: molecular machinery deciphered. Biochemical, physiological and molecular avenues for combating abiotic stress tolerance in plants. Academic Press, p. 57-71. https://doi.org/10.1016/B978-0-12-813066-7.00004-8

15. Palmer S. 2017. The roles of residue position and charge in the cryoprotective behaviour of the Vitis riparia $\mathrm{K} 2$ and YSK2 dehydrins: doctoral dissertation. University of Guelph, Canada, 92 p. http://hdl.handle.net/10214/11598

16. Polashock J. J., Arora R., Peng Y., Naik D., Rowland L. J. 2010. Functional identification of a C-repeat binding factor transcriptional activator from blueberry associated with cold acclimation and freezing tolerance. Journal of the American Society for Horticultural Science, 135 (1): 40-48. https://doi.org/10.21273/JASHS.135.1.40

17. Ponomarenko V. V., Ponomarenko K. V. 2012. N. I. Vavilov ideas in modern studies of the genus Malus Mill. - apple tree. Works on Applied Botany, Genetics and Selection, 169: 225-229 (in Russian).

18. Ponomarev A. G., Tatarinova T.D., Perk A.A., Vasilyeva I. V., Bubyakina V. V. 2013. Features of proteins associated with the formation of frost hardiness in two populations of Betula platyphylla in Yakutia. Modern Problems of Science and Education, 1: 341-349 (in Russian).

19. Preston J. C., Sandve S. R. 2013. Adaptation to seasonality and the winter freeze. Frontiers in Plant Science, 4: 167. https://doi.org/10.3389/fpls.2013.00167

20. Rachenko M. A., Rachenko E. I., Korzinnikov Yu. S. 2011 Studying the adaptivity of apple varieties in Pre-Baikal area. Bulletin of the Russian Academy of Agricultural Science, 4: 36-40 (in Russian).

21. Salojärvi J., Smolander O. P., .... Kangasjärvi J. 2017. Genome sequencing and population genomic analyses provide insights into the adaptive landscape of silver birch. Nature Genetics, 49 (6): 904-912. https://doi.org/10.1038/ng.3862

22. Sasaki R., Yamane H., Ooka T., Jotatsu H., Kitamura Y., Akagi T., Tao R. 2011. Functional and expressional analyses of PmDAM genes associated with endodormancy in Japanese apricot. Plant Physiology, 157 (1): 485-497. https://doi.org/10.1104/pp.111.181982

23. Shin H., Oh S. I., Kim M. A., Yun S. K., Oh Y., Son I. C. Kim D. 2015. Relationship between cold hardiness and dehydrin gene expression in peach shoot tissues under field conditions. Horticulture, Environment, and Biotechnology, 56 (3): 280-287. https://doi.org/10.1007/s13580-015-0147-5
24. Strimbeck G. R., Schaberg P. G., Fossdal C. G., Schröder W. P., Kjellsen T. D. 2015. Extreme low temperature tolerance in woody plants. Frontiers in Plant Science, 6: 884. https://doi.org/10.3389/fpls.2015.00884

25. Tatarinova T. D., Ponomarev A. G., Perk A. A., Vasilyeva I. V., Bubyakina V. V. 2011. Seasonal changes in the content of dehydrins of Betula platyphylla Sukacz. buds associated with the formation of resistance to the extreme climate of Yakutia. Bulletin of St. Petersburg State University, 3 (4): 107-114 (in Russian).

26. Tatarinova T. D., Bubyakina V. V., Vetchinnikova L. V., Perk A. A., Ponomarev A. G., Vasilyeva I. V. 2017. Stress dehydrin proteins in birch buds in climate-contrasting regions. Cytology, 59 (2): 156-160 (in Russian).

27. Timmons T. M., Dunbar B. S. 1990. Protein blotting and immunodetection. Methods in Enzymology, 182: 679-688. https://doi.org/10.1016/0076-6879(90)82053-5

28. Tunnacliffe A., Wise M. J. 2007. The continuing conundrum of the LEA proteins. Naturwissenschaften, 94 (10): 791-812. https://doi.org/10.1007/s00114-007-0254-y

29. VasilyevaI.V.,TatarinovaT. D., Vetchinnikova L. V., Perk A. A., Ponomarev A. G., Serebryakova O. S., Petrova N. E. 2018. Composition of dehydrins of different species of birch in conditions of cold regions. Mechanisms of plant and microorganism resistance to adverse environmental conditions. Proceedings of the annual meeting of the Society of Plant Physiologists of Russia, All-Russian Scientific Conference with International Participation and School of Young Scientists. V. B. Sochava Institute of Geography RAS SB, 2 (I): 180-184. (in Russian). https:/doi.org/10.31255/978-5-94797-319-8-180-184

30. Wisniewski M., Bassett C., Gusta L. V. 2003. An overview of cold hardiness in woody plants: seeing the forest through the trees. HortScience, 38 (5): 952-959. https://doi.org/10.21273/HORTSCI.38.5.952

31. Wisniewski M., Nassuth A., Teulières C., Marque C., Rowland J., Cao P. B., Brown A. 2014. Genomics of cold hardiness in woody plants. Critical Reviews in Plant Sciences, 33 (2-3): 92-124. https://doi.org/10.1080/07352689.2014.870408

32. Yamane H. 2014. Regulation of bud dormancy and bud break in Japanese apricot (Prunus mume Siebold \& Zucc.) and peach (Prunus persica (L.) Batsch): a summary of recent studies. Journal of the Japanese Society for Horticultural Science, 83 (3): 187-202. https://doi.org/10.2503/jishs1.CH-Rev4

33. Zamani Bahramabadi E., Jonoubi P., Rezanejad F. 2018. Some cytological and physiochemical features relating to non-storability of pistachio (Pistacia vera $\mathrm{L}$.) pollen. Grana, 57 (6): 456-463.

https://doi.org/10.1080/00173134.2018.1476584

ISSN 1392-3196 / e-ISSN 2335-8947

Zemdirbyste-Agriculture, vol. 107, No. 2 (2020), p. 185-190

DOI 10.13080/z-a.2020.107.024

\title{
Dehidrinų šeimos baltymų, besiskiriančių atsparumu šalčiui, kiekio kitimas Malus spp. žievèje Pietų Baikalijos sąlygomis
}

\author{
M. A. Rachenko, A. M. Rachenko \\ Rusijos mokslų akademijos Sibiro filialas Sibiro augalų fiziologijos ir biochemijos institutas
}

\section{Santrauka}

Tyrimo tikslas - ištirti obels (Malus spp.) dehidrinų šeimos baltymų dinamiką Pietų Baikalijos sąlygomis. Tyrimo objektas - sibirinè uogine obelis ir naminė obelis, taip pat ịvairiu kartų tarprūšiniai hibridai, kurie lauko tyrimu metu atskleidè atsparumo šalčiui skirtumus. Augalinès medžiagos mėginiai buvo imti kas mènesị (nuo rugsèjo iki gegužès) dvejus tyrimo metus. Tyrimo rezultatai parodè, kad kokybinè dehidrinų šeimos baltymų sudètis obelų medžiu žieveje nepriklausè nuo veislès. Baltymai, kurių masè $63,60,52,45,34$ ir $32 \mathrm{kD}$, buvo nustatyti visu tirtų obels genotipų dehidrinų spektre. Dehidrinų šeimos baltymas, kurio mase $52 \mathrm{kDa}$, buvo aptinkamas visą obelų ramybès laikotarpị. Kitu baltymu skaičius varijavo priklausomai nuo sezono. Buvo nustatyti reikšmingi 60 ir $34 \mathrm{kDa}$ masés baltymų skirtumai. Aptikti $34 \mathrm{kDa}$ dehidrino kiekio svyravimo ypatumai gali būti siejami su adaptyviniu obelų medžių potencialu Pietų Baikalijos sąlygomis.

Reikšminiai žodžiai: atsparumas šalčiui, dehidrinai, obelis, veislès. 